DOI: $10.17516 / 1997-1370-0555$

УДК 81 '272

\title{
Ethnic Language Use as a Symbol of Keeping the Nation's Culture and Traditions (the Case of the Displaced Peoples' Languages in the Kurdistan Region)
}

\author{
Rizgar M. Ameen and Oksana V. Magirovskaya* \\ Siberian Federal University \\ Krasnoyarsk, Russian Federation
}

Received 20.01.2020, received in revised form 01.02.2020, accepted 04.03.2020

\begin{abstract}
The research focuses on the role of ethnic language in keeping culture and traditions of the displaced people who fled to the Kurdistan region of Iraq due to the threats on their lives. It aims at exploring the use of the displaced people's ethnic language in different occasions in daily activities and the ways it determines the language maintenance and, consequently, favors the displaced peoples' culture and traditions. It is shown that family, religion, media, emotional and psychological sphere of a human's life are the domains which can be considered the most effective ones, as ethnic language keeps its dominance there. The novelty of the research is clear due to the vast research interest to such a high migrated region with a changing political situation as Kurdistan. The conducted sociolinguistic analysis of the language situation in this region is the first among its linguistic studies and serves a basis for further research work.
\end{abstract}

Keywords: Kurdistan, high migrated region, displaced people, ethnic language use, ethnic culture and traditions.

Research area: philology.

Citation: Ameen, R.M., Magirovskaya, O.V. (2020). Ethnic language use as a symbol of keeping the nation's culture and traditions (the case of the displaced peoples' languages in the Kurdistan Region). J. Sib. Fed. Univ. Humanit. Soc. Sci., 13(3), 286-295. DOI: 10.17516/1997-1370-0555.

\footnotetext{
(C) Siberian Federal University. All rights reserved

* Corresponding author E-mail address: rizgarmuhammad1983@gmail.com, magirovskayaov@yandex.ru ORCID: 0000-0001-8419-388X (Ameen); 0000-0003-4286-2613 (Magirovskaya) 


\section{Introduction}

Keeping culture and traditions has always been the subject matter to concern. The issue is especially vital for high migrated regions with daily situations of language contacts, Kurdistan being one of them on the map of the world.

The displaced people have been settling in the Kurdistan Region of Iraq since 2003. They can be viewed as one of those ethnic groups who preserve their culture and traditions through using their ethnic language in different domains. The displaced people are from different nations. Most of them are Arabs; there are also Turkmen and Assyrians. They are mostly from Mosul governorate on the border of Turkey and the Kurdistan region; some of them are from the central and northern part of the country. Their stay for years has left no chance for them to have a contact with the Kurdish language, since in a contact situation like migration one ethnic group comes into contact with another, the host society often exerting cultural influence on the immigrant group (Weinreich, 1953).

Still, the Kurds also have a chance to share their culture and traditions with the host society. This takes place when the natives get in contact with the displaced people and, consequently, with the Kurdish language, which is a Western Iranian language with two major dialects (Sorani and Kurmanji). Due to this challenge the situation in the Kurdistan region is worth being analyzed from a sociolinguistic point of view. This aspect of linguistic knowledge can provide a thorough description of the linguistic situation in the regions of multiple language contact and analyze the linguistic outcomes (language maintenance or language shift) of such contact and their effect (positive or negative) on the displaced people's culture and traditions.

\section{Language maintenance}

\section{as a factor to keep culture and traditions}

Language maintenance is a situation in which a language maintains its vitality, even under pressure (Batibo, 2005). It implies, therefore, that the degree of resistance is strong enough to contain any pressure that may be coming from a dominant language.
In a situation of language maintenance, the domains of mother tongue remain largely the same and transmission of the language to the children is active and as perfect as possible (Batibo, 2005). Moreover, the number of speakers remains relatively stable and they maintain a strong allegiance to their language.

The term of the language maintenance is defined differently by the scholars. For Ferguson it is "the preservation of the use of a language by a speech community under conditions where there is a possibility of shift to another language" (Ferguson, Heath, 1981: 530). Hofman and Cais define the language maintenance as the national ideal of a cultural 'melting pot', because they mostly regard their countries with a constant influx of immigrants going hand in hand with stressing a shift toward the common language of the new country (Hoffman, Cais 1984). For some scholars, language maintenance refers to the situation where speech community continues to use its traditional language in the face of a host of conditions that might foster a shift to another language. Veltman is one of these scholars. He argues that "language maintenance is the practice of speaking one's mother tongue throughout one's lifetime as the only language in daily use" (Veltman, 1991: 147). Yet, for Paulston the term is much more important. He states that language maintenance can be seen as a social resource by ethnic groups in competition for access to goods and services of a nation, and that language loyalty is not a natural phenomenon but a deliberately chosen strategy for group survival (Paulston C.B., Paulston R.G., 1980). Fasold defines language maintenance as "the long term collective result of language choice" (Fasold, 1984: 212). Moreover, the scholar claims that language maintenance occurs when the members of a given community decide to keep on using the language that their ancestors traditionally used (Fasold, 1984: 213).

There are different factors which may help people maintain their ethnic language. Fillmore states that there are internal and external factors that lead to the loss of the native language (Fillmore, 2000). The internal force for this choice is the preference for social acceptance and conformity to the dominant group 
as well as the necessity to communicate with those members. On the other hand, the external pressure comes from the sociopolitical reason when the society opposes differences, divergence, and aliens.

Classifying the factors is a bit different for Weinreich who gives more details when he mentions that there is a relationship between ethnic languages and extra-linguistic factors like cultural, psychological, social and historical processes as well as non-linguistic factors like geographic areas, religion, race, sex, age, social status, occupation, all the factors leading to creating linguistic divisions between mother-tongue groups (Weinreich, 1953). According to his investigations, "some ethnic groups stick to their mother language because of the emotional involvement with it, as one learned it in childhood or because of the role of language as a symbol of group integrity" (Weinreich, 1953: 90).

Dorian discusses many other factors that lead to language maintenance. These are age and the use of language in a specific domain which have a great effect in maintaining the language and even in its transition to the next generation (Dorian, 1981).

The influence of the above factors is not the same in maintaining the languages. Factors like family, parents, and grandparents have greater role than others. Fillmore mentions that there is a role for family to play in minority children's first language maintenance. Parents have to be encouraged to find time to talk with their children, read to them (if this is a practice in the culture of the home), and teach them things that interest educated members of their group. Families that come from cultures with a rich oral tradition will have many stories and histories to share with the children. Teachers need to encourage them to use these materials and to regard them as equal to written materials that other families might use with their children at home (Fillmore, 2000). Clyne explains the importance of grandparents in the mother tongue maintenance. The home domain and particularly relations with older relatives who do not speak the national language well is one of the situations that elicit the use of the community language (Clyne, 1982).
Thus, language maintenance can be seen as the situation when the community members keep maintaining their ethnic language through using it in different domains because they regard it as a symbol of their culture and traditions.

\section{Design and Methodology}

The research aims at presenting the role of the displaced people's ethnic language use in keeping their culture and traditions in the Kurdistan region of Iraq and at identifying the prospects for the functioning of the minority's languages in this territory in the future.

The design applied in our research is interactive: multiple data gathering procedures were employed for the current purposes. To achieve the objectives of the research a sociolinguistic questionnaire was designed, community profile technique was used, and informal interviews were held.

The community profile is considered the main method of gathering information about the displaced people in the territory of the Kurdistan region of Iraq. It contains historical and sociolinguistic data relevant for the analysis of the language situation. These data are covered by the facts about 80 respondents who were purposively selected from different areas of the region. The demographic background information about the participants' general background includes the data about gender, age, ethnicity, marital status, residency, level of education, length of stay in Kurdistan, and the extent of language use.

The interviews were conducted with eight members of the community out of total 80 . The questions were developed following the method used in several previous studies, i.e. Dweik (2000) and Al-Refa'i (2013). These questions covered historical and demographic data, occupational distribution, education, ethnicity, associations, residential composition, and communication peculiarities.

The questionnaire was composed specifically to meet the needs of our research, and namely to investigate the role of ethnic language use in keeping the displaced people's culture and traditions. It consisted of five parts and relied on similar previous question- 
naires designed by the researchers who studied many ethnic minorities in different places in the world (Fishman, 1966; Dweik, 2000; Tuwakham, 2005; Nofal, 2011; Habtoor, 2012; et al.). Yet, it was adapted and modified by changing the items to suit the community under the research. Our questionnaire is characterized by (1) prescribed wording and order of questions to ensure that each respondent receives the same stimuli, (2) prescribed definitions or explanations for each question to ensure the interviewers handle questions consistently and can answer the respondents' requests for clarification if they occur, and (3) prescribed response format to enable rapid completion of the questionnaire during the interviewing process. The questionnaire was validated and tested before it was administered to a sample of participants from the displaced people in the Kurdistan region.

Analysis of the impact of ethnic language use on keeping culture and traditions of the displaced people in the Kurdistan region is one of the main goals of our research. For this purpose the following questions were suggested to the respondents:

- What language do you use to talk to your spouse, parents, brothers/sisters and grandparents?

- What language do you use in the neighborhood with your neighbours, acquaintances, and friends?

- What language do you use at school, at work, to greet people, to worship?
- What language do you prefer to follow the media?

- What language do you use to express your emotions?

\section{Findings}

The analysis results (see Table 1) show that home domain is still the key one for the ethnic language use, since it is not going to survive unless it is transmitted in home. Thus, the majority of the respondents (from $63 \%$ to $81 \%$ ) need their ethnic language to talk to their spouse, parents, children, brothers/sisters and grandparents in their native language. They also prefer speaking it (but not Kurdish) when they keep in touch with family members during phone calls and various meetings.

We claim that using ethnic language at home and among family members means a lot for the displaced people, since they see it as a reason to maintain and keep their native language from death and to preserve their national identity as well. The results also prove the grandparents' great role in language maintenance as this generation often speak only the mother tongue and not the language(s) of the host society ( 65 respondents out of 80 confirm that they speak mostly or only their native language with their grandparents).

Concerning the language used in the neighbourhood, the participants' Kurdish language use is more frequent compared to the cases of the ethnic language use in communication with the family members and relatives.

Table 1. Language use at home and among the family members

\begin{tabular}{|l|c|c|c|c|c|c|}
\hline What language do you speak with & $\begin{array}{c}\text { only } \\
\text { Kurdish }\end{array}$ & $\begin{array}{c}\text { mostly } \\
\text { Kurdish }\end{array}$ & $\begin{array}{c}\text { Kurdish } \\
\text { and ethnic }\end{array}$ & $\begin{array}{c}\text { mostly } \\
\text { ethnic }\end{array}$ & $\begin{array}{c}\text { only } \\
\text { ethnic }\end{array}$ & total \\
\hline your spouse? & 8 & 5 & 14 & 9 & 44 & 80 \\
\hline your parents? & 5 & 5 & 15 & 9 & 46 & 80 \\
\hline your children? & 6 & 5 & 12 & 9 & 48 & 80 \\
\hline your brothers / sisters? & 6 & 5 & 17 & 7 & 45 & 80 \\
\hline your grandparents? & 5 & 4 & 6 & 15 & 50 & 80 \\
\hline at family meetings? & 5 & 3 & 14 & 8 & 50 & 80 \\
\hline family members during phone calls? & 5 & 6 & 18 & 4 & 47 & 80 \\
\hline your relatives during phone calls? & 4 & 6 & 18 & 6 & 46 & 80 \\
\hline your relatives when meeting them? & 6 & 5 & 14 & 6 & 49 & 80 \\
\hline
\end{tabular}


The results (see Table 2) show that $51.25 \%$ of the respondents use their ethnic language when they go outside their home territory, $12.5 \%$ of them use both languages and $36.25 \%$ use the Kurdish language. $41-45 \%$ of them use ethnic with their acquaintances and friends in the neighborhood, in weddings and social occasions, while $16-21 \%$ use both languages and 37$39 \%$ use the Kurdish language that is twice bigger than the correspondent figure for the cases of communication with the family members. This seems natural and it logically relates to the fact that the need to use the host language outdoors is greater and, thus, the ethnic language has a lesser chance to be maintained.

The analyzed situations demonstrate that Kurdish and ethnic languages are used by the displaced people when they talk with their friends and people in the neighborhood and when they talk with their colleagues and bosses. They use Kurdish due to mixing with other people from other minorities who do not know their ethnic language. This all means that language change is inevitable one day and for some people the language required for securing a job is more important than the maintenance of the mother tongue.

Due to the fact that the school programmes are mostly in Kurdish and teachers and running staff are Kurdish speakers the participants have less chance to practice their native language (see Table 3). Using ethnic language is in a lesser degree and using mixed languages is, consequently, in a higher degree compared to the work domain. According to the results, $42-46 \%$ of the participants use ethnic language when they talk with their classmates, teachers and school running staff, $17-25 \%$ use both languages whereas $36-43 \%$ use the Kurdish language, the figures of the Kurdish language use increasing for the cases of communication with the school running staff.

When it comes to greeting new people in the street or introducing themselves to new people just two-fifths of the respondents use their ethnic language, about one fourth of them use mix language (Kurdish and ethnic) and around one third use only Kurdish (see Table 4).

Compared to the previous domains, the sphere of interpersonal communication during the first contacts with new people (greetings and introducing oneself) shows the lowest rate of the ethnic language use. It may be related to the fact that the introduction words are the most repeated words daily. Moreover, they are easier to get as they are rather short and clear.

Ethnic language use reaches its highest degree in the situations of pray (see Table 5). This is due to the fact that the majority of the partic-

Table 2. Language use in the neighborhood

\begin{tabular}{|l|c|c|c|c|c|c|}
\hline $\begin{array}{c}\text { What language do you use } \\
\text { in the neighborhood with }\end{array}$ & $\begin{array}{c}\text { only } \\
\text { Kurdish }\end{array}$ & $\begin{array}{c}\text { mostly } \\
\text { Kurdish }\end{array}$ & $\begin{array}{c}\text { Kurdish } \\
\text { and ethnic }\end{array}$ & $\begin{array}{c}\text { mostly } \\
\text { ethnic }\end{array}$ & $\begin{array}{c}\text { only } \\
\text { ethnic }\end{array}$ & total \\
\hline your neighbors? & 13 & 16 & 10 & 7 & 34 & 80 \\
\hline your acquaintances? & 15 & 15 & 17 & 4 & 29 & 80 \\
\hline your friends in the neighbouurhood? & 16 & 15 & 13 & 3 & 33 & 80 \\
\hline $\begin{array}{l}\text { your friends in weddings } \\
\text { and social occasions? }\end{array}$ & 17 & 14 & 14 & 4 & 31 & 80 \\
\hline
\end{tabular}

Table 3. Language use at educational institutions

\begin{tabular}{|l|c|c|c|c|c|c|}
\hline $\begin{array}{c}\text { What language do you use at school, } \\
\text { university, language courses with }\end{array}$ & $\begin{array}{c}\text { only } \\
\text { Kurdish }\end{array}$ & $\begin{array}{c}\text { mostly } \\
\text { Kurdish }\end{array}$ & $\begin{array}{c}\text { Kurdish } \\
\text { and ethnic }\end{array}$ & $\begin{array}{c}\text { mostly } \\
\text { ethnic }\end{array}$ & $\begin{array}{c}\text { only } \\
\text { ethnic }\end{array}$ & total \\
\hline your classmates? & 16 & 13 & 17 & 2 & 32 & 80 \\
\hline your teachers? & 13 & 16 & 14 & 4 & 33 & 80 \\
\hline school staff? & 11 & 14 & 20 & 3 & 32 & 80 \\
\hline
\end{tabular}


Rizgar M.Ameen and Oksana V. Magirovskaya. Ethnic Language Use as a Symbol of Keeping the Nation's Culture and Traditions...

Table 4. Language use in the communicative acts of greeting and meeting new people

\begin{tabular}{|l|c|c|c|c|c|c|}
\hline \multicolumn{1}{|c|}{ What language do you use to } & $\begin{array}{c}\text { only } \\
\text { Kurdish }\end{array}$ & $\begin{array}{c}\text { mostly } \\
\text { Kurdish }\end{array}$ & $\begin{array}{c}\text { Kurdish } \\
\text { and ethnic }\end{array}$ & $\begin{array}{c}\text { mostly } \\
\text { ethnic }\end{array}$ & $\begin{array}{c}\text { only } \\
\text { ethnic }\end{array}$ & total \\
\hline greet people in the street? & 17 & 12 & 18 & 3 & 30 & 80 \\
\hline introduce yourself to new people? & 18 & 10 & 20 & 4 & 28 & 80 \\
\hline
\end{tabular}

Table 5. Language use in the place of worship

\begin{tabular}{|l|c|c|c|c|c|c|}
\hline \multicolumn{1}{|c|}{ What language do you use } & $\begin{array}{c}\text { only } \\
\text { Kurdish }\end{array}$ & $\begin{array}{c}\text { mostly } \\
\text { Kurdish }\end{array}$ & $\begin{array}{c}\text { Kurdish } \\
\text { and ethnic }\end{array}$ & $\begin{array}{c}\text { mostly } \\
\text { ethnic }\end{array}$ & $\begin{array}{c}\text { only } \\
\text { ethnic }\end{array}$ & total \\
\hline when you invoke / pray? & - & - & 3 & 9 & 68 & 80 \\
\hline $\begin{array}{l}\text { when you speak with your } \\
\text { fellow worshippers? }\end{array}$ & 9 & 9 & 13 & 9 & 40 & 80 \\
\hline to read religious advice? & - & - & 7 & 8 & 65 & 80 \\
\hline to talk to Imam? & 8 & 8 & 15 & 8 & 41 & 80 \\
\hline
\end{tabular}

Table 6. Language and media

\begin{tabular}{|l|c|c|c|c|c|c|}
\hline \multicolumn{1}{|c|}{ What language do you prefer to } & $\begin{array}{c}\text { only } \\
\text { Kurdish }\end{array}$ & $\begin{array}{c}\text { mostly } \\
\text { Kurdish }\end{array}$ & $\begin{array}{c}\text { Kurdish } \\
\text { and ethnic }\end{array}$ & $\begin{array}{c}\text { mostly } \\
\text { ethnic }\end{array}$ & $\begin{array}{c}\text { only } \\
\text { ethnic }\end{array}$ & total \\
\hline listen to the radio? & 8 & 9 & 15 & 9 & 39 & 80 \\
\hline watch news channels? & 9 & 11 & 16 & 9 & 35 & 80 \\
\hline watch entertainment programmes? & 10 & 10 & 11 & 8 & 41 & 80 \\
\hline read newspapers? & 10 & 7 & 16 & 7 & 40 & 80 \\
\hline use social sites? & 11 & 6 & 14 & 9 & 40 & 80 \\
\hline
\end{tabular}

ipants are Arabs and Arabic is the language of Quran and worship not for the Arabs only but for all Muslims around the world, too. So, the obtained results show that the majority $(96.25 \%$ of the participants) use ethnic language when they pray, $91.25 \%$ - when they read religious advice, $61.25 \%$ - when they speak with their fellow worshippers, and $61.25 \%$ - when they talk to Imam.

The results mentioned above in Table 5 prove that the role of religion in language maintenance can be a strong and important mechanism. The classical religious texts are also of significance here as they successfully maintain the intergenerational language maintenance and transmission.

The media is also the sphere which contributes to language maintenance (see Table 6). According to the results, more than a half of the participants prefer using their ethnic language while listening to the radio, watching news and entertainment channels, reading newspapers and using social sites, whereas only about onefifth of them use both languages.

Due to the fact that the media in the Kurdistan region are not for the Kurds only, other ethnic groups have their own media. That is the reason why the displaced people of the region have a chance to enjoy listening and watching programmes in their ethnic language. The results show that the ethnic language is still their choice. In the situation like this the media positively affects the status and the prestige of the ethnic language.

Personal sphere is also viewed as an indicator of the ethnic language maintenance. The analysis of the results (see Table 7) show that three-fifths of the participants (55-64\%) use their ethnic languages to have dreams or when they get angry, anxious, confused, 
Table 7. Language use and emotional self-expressions

\begin{tabular}{|l|c|c|c|c|c|c|}
\hline \multicolumn{1}{|c|}{ What language do you use } & $\begin{array}{c}\text { only } \\
\text { Kurdish }\end{array}$ & $\begin{array}{c}\text { mostly } \\
\text { Kurdish }\end{array}$ & $\begin{array}{c}\text { Kurdish } \\
\text { and ethnic }\end{array}$ & $\begin{array}{c}\text { mostly } \\
\text { ethnic }\end{array}$ & $\begin{array}{c}\text { only } \\
\text { ethnic }\end{array}$ & total \\
\hline in your dreams? & 12 & 8 & 16 & 8 & 36 & 80 \\
\hline $\begin{array}{l}\text { when you are angry, anxious, } \\
\text { confused or embarrassed? }\end{array}$ & 10 & 8 & 14 & 8 & 40 & 80 \\
\hline to show your happiness? & 10 & 5 & 14 & 13 & 38 & 80 \\
\hline
\end{tabular}

embarrassed or showing their happiness whereas only one-fourth of them (19-25\%) use Kurdish.

Such results are mainly due to the fact that emotions and feelings are personal and psychological issues, they deserve to be expressed in a language that is the most intimate to a human. The results we have obtained prove that the ethnic language is still the language of emotional and psychological life of the displaced people. Thus, it serves a good basis for the nation's culture and traditions.

\section{Discussion}

The use of language among the displaced people in the Kurdistan region is different in various domains. In some domains such as family, religious issues, emotional self-expressions and media ethnic language is still more preferable. In neighborhood, education, conducting business, greeting people and talking to governmental officials both languages (Kurdish and ethnic) are in circulation.

For the displaced people family is still a very strong domain to keep and maintain their ethnic language. This matches Clyne's conception that language is not going to survive another generation unless it is transmitted in the home, within the family (Clyne, 2003; Clyne, 2005). In the family domain the use of the ethnic language is in a higher degree when the other generations talk to their grandparents. This shows the grandparents' significant role in maintaining the ethnic language and agrees with Holmes' study of various communities in New Zealand. The scholar revealed that grandparents and older parents in the Greek community are very often monolingual and younger people have to translate for these older people, especially in the situations where the older people are, for example, shop owners (Holmes et al., 1993).

Religious issues are also very vital. The majority of the displaced people in Kurdistan use their ethnic language while praying and being the participants of the religious ceremonies. This result matches with Baker's point of view about the role of religion in language maintenance. The scholar argues that religion can be a strong and important vehicle for the maintenance of a majority and a minority language. The use of classical Arabic in Islam, Hebrew in Judaism, and German among the Protestant Old Order Amish in Pennsylvania illustrates that religion can be a preserver of the language (Baker, 2011). Fishman also reports that classical religious texts such as the Quranic Arabic, Prayer book and Old Testament have successfully maintained intergenerational language maintenance and transmission (Fishman, 1991).

Ethnic language for emotional self-expression and media also more preferable for more than a half of the displaced people in Kurdistan. This situation matches Weinreich's observation that some ethnic groups stick to their mother language because of the emotional involvement with it, as one learned it in childhood or because of the role of language as a symbol of group integrity (Weinreich, 1953). Baker (2011), Cormack (2007), Namei (2012), Pauwels (2005) et al., in their turn, put the media in the focus of their attention and, thus, argue that media can be one of the important institutional support factors that are needed for the language maintenance.

The signs of language shift are seen in the situations of interpersonal daily contacts which are ineviTable in the territories of diverse popu- 
lation. The areas of such contacts are neighborhood, education, conducting business, greeting people, talking to governmental officials etc. This can be seen as the partial language shift and agrees with Fishman's conception which runs that the ethnic language is replaced only in certain areas of interaction and "a new pattern of inter-generational continuity is then stabilized" (Fishman, 1989: 178).

\section{Conclusion}

Ethnic language which is still much more preferred among the majority of the displaced people in the Kurdistan region at the most important domains of the humans' lives can be viewed as a strong proof of the displaced people's strive for their national identity and cultural unity. Attitude of the displaced people towards using their ethnic language is still high. According to the results of our research, about three-fifth of them see their ethnic lan- guage as a symbol of keeping their culture and traditions.

At the same time they do not hide the value of the Kurdish language for having a better future for themselves and their children in the region. This fact seems very important and serves a significant characteristic feature of the language situation in Kurdistan. Thus, the displaced people use Kurdish when they talk to their friends in the neighborhood, communicate with their teachers and their friends at school and university as well as when they meet new people, speak with government officials, in shopping or at work.

What makes the language situation in the Kurdistan region peculiar is the use of both languages (the ethnic language and Kurdish) in the media domain. The displaced people's choice is still with the ethnic language. Yet, their tolerance and interest in Kurdish might serve a good platform for the dialogue of different cultures.

\section{References}

Al-Rafa'i, T.J. (2013). The Language Situation among the Assyrians of Jordan: A Sociolinguistic Study: a thesis submitted in partial fulfilment of the requirements for the Master of Arts in English Language. Middle East University, 119 p. 498 p.

Baker, C. (2001). Foundation of bilingual education and bilingualism. Clevedon, Multilingual matters,

Batibo, H.M. (2005). Language decline and death in Africa: Causes, consequences and challenges. Clevedon, Buffalo, Multilingual Matters, 192 p.

Clyne, M. (1982). Multilingual Australia: resources, needs, policies. Melbourne, River Seine, 178 p.

Clyne, M. (2003). Dynamics of language contact English and immigrant languages. Cambridge, Cambridge University Press, $282 \mathrm{p}$.

Clyne, M. (2005). Australia's language potential. Sydney, University of New South Wales Press., 208 p.

Cormack, M. (2007). The media and language maintenance. In Cormack M.J. \& Hourigan N. (eds.) Minority language media: Concepts, critiques and case studies. Clevedon, Multilingual matters, 52-68.

Dorian, N.C. (1981). Language Death. The Life Cycle of a Scottish Gaelic Dialect. Philadelphia, University of Pennsylvania Press, 206 p.

Dweik, B. (2000). Linguistic and cultural maintenance among the Chechens of Jordan. In Language, Culture and Curriculum, 13 (2), 184-195.

Fasold, R. (1984). Sociolinguistics of society. Oxford and New York, Basil Blackwell Inc., 335 p.

Ferguson, C., Heath, S. (1981). Language in USA. New York, Cambridge University Press, 592 p.

Fillmore, L.W. (2000). Loss of family languages: Should educators be concerned? In Theory into Practice, 39 (4), 203-210.

Fishman, J.A. (1966). Language loyalty in the United States. The Hague, Mouton, 478 p.

Fishman, J.A. (1989). Language and ethnicity in minority sociolinguistic perspective. Clevedon, Multilingual Matters, $717 \mathrm{p}$.

Fishman, J.A. (1991). Reversing language shift: Theory and practice of assistance to threatened languages. Clevedon, Multilingual Matters, 413 p. 
Habtoor, H. (2012). Language maintenance and language shift among second generation Tigrinya-speaking Eritrean immigrants in Saudi Arabia. In Theory and Practice in Language Studies, 2 (5), 945-955.

Hoffman, J. \& Cais, J. (1984). Children's attitudes to language maintenance and shift. In lnternational Journal of the Sociology of Language, 50,147-153.

Holmes, J., Roberts, M., Verivaki, M. \& Aipolo, A. (1993). Language maintenance and shift in three New Zealand speech communities. In Applied linguistics, 14 (1), 1-24.

Namei, S. (2012). Iranians in Sweden. A study of language maintenance and shift. Sweden, Uppsala University, $246 \mathrm{p}$.

Nofal, Yu. M. (2011). The language situation among the Indians of Yemen: A Sociolinguistic study. A thesis submitted in partial fulfilment of the requirements for the master's degree of Arts in English Language. Middle East University, $121 \mathrm{p}$.

Paulston, C.B., Paulston, R.G. (1980). Language and ethnic boundaries. In Language Sciences, Vol. 2 (1), 69-101.

Pauwels, A. (2005). Maintaining the community language in Australia: Challenges and roles for families. In International Journal of Bilingual Education and Bilingualism, 8 (2-3), 124-131.

Tuwakham, M. (2005). Language vitality and language attitude among the Yong people in Lamphun province: a sociolinguistic study: A thesis submitted in partial fulfilment of the requirements for the Degree of Master Arts in Linguistics. Chiang Mai, Thailand, Payap University, $191 \mathrm{p}$.

Veltman, C. (1991). Theory and method in the study of language shift. In Dow, J.R. (Ed.) Focus on Language and Ethnicity: Essays in honour of Joshua A. Fishman, Vol. 2, 145-168.

Weinreich, U. (1953). Languages in contact: Findings and problems. New York, 148 p. 


\title{
Этнический язык как символ сохранения культуры и традиций (на примере языковой ситуации вынужденных переселенцев на территории Курдистана)
}

\author{
Р.М.Амин, О.В. Магировская \\ Сибирский федеральный университет \\ Российская Федерачия, Красноярск
}

\begin{abstract}
Аннотация. В статье рассматривается роль этнического языка в сохранении культуры и традиций большой группы вынужденных переселенцев, бежавших в Иракский Курдистан из-за угрозы их жизни на родной территории проживания. Результаты социолингвистического анализа позволяют выявить области повседневной жизни и деятельности, которые во многом обусловливают сохранение этнического языка и, следовательно, благоприятствуют развитию этнической культуры и традиций. Наиболее эффективными выступают семья, религия, средства массовой информации и эмоционально-психологическая сторона проявления личности. Новизна исследования во многом определяется выбором региона исследования - территории Курдистана - как региона высокой миграции, который является областью интереса многих научных направлений в силу актуальности происходящих политических событий. Социолингвистический анализ языковой ситуации в данном регионе проводится впервые.
\end{abstract}

Ключевые слова: Курдистан, регион высокой миграции, вынужденные переселенцы, использование этнического языка, этническая культура и традиции.

Научная специальность: 10.00.00 - филологические науки. 